\title{
Kirjoja
}

\author{
Markus Vinnari ${ }^{\mathrm{a}}$
}

\section{Teknologiauskoisen visio ruokavallankumouksesta}

\author{
Paul Shapiro: \\ Clean Meat: How Growing Meat Without Animals Will Revolutionize Dinner and the World. \\ Gallery books, New York 2018.
}

Ruokajärjestelmämme on valtavien mullistusten keskellä. Globaalit markkinat ovat lisäämässä tarjontaa ennennäkemättömän suureksi, tuottajien määrä on vähenemässä todella nopeasti ja teknologinen kehitys mahdollistaa aivan uudentyyppisten tuotteiden tulemisen markkinoille. Samaan aikaan vaatimukset ruoankulutuksellemme ovat muuttuneet todella radikaalisti. Järjestelmä, joka on optimoitu tuottamaan vain muutamia raaka-aineita mahdollisimman halvalla, on vahingoittamassa sekä meitä kuluttajia että ympäristöä peruuttamattomalla tavalla.

Yhtenä ratkaisuna tähän ongelmaan teknologiakeskeistä ratkaisua ajavat toimijat ovat esittäneet yhä suuremman osan ruoantuotannosta siirtämistä laboratorioihin ja bioreaktoreihin. Uudessa kirjassaan Clean Meat Paul Shapiro käy läpi, kuinka nämä kehitysaskeleet ovat edenneet tähän päivään mennessä ja kuinka tulevaisuudessa voitaisiin edistää ruoantuotannon siirtymistä laboratorioihin.

Paul Shapiro on pitkän linjan eläinasia-aktivisti, joka on ollut mukana aikaisemmin perustamassa ja johtamassa suuria yhdysvaltalaisia eläinten hyvinvointiin ja kohteluun keskittyneitä järjestöjä. Shapiro on sittemmin siirtynyt yrityspuolelle, ja nykyisin hän on mukana yrityksessä, jonka tarkoituksena on helpottaa liha-alan yrityksiä lisäämään kasvisperäisiä raakaaineita tuotteisiinsa.

Jo kirjan nimessä "Clean Meat" on yksi kirjan tärkeimmistä viesteistä: tuotteen nimeämisellä on todella keskeinen rooli siinä, kuinka hyvin kuluttajat ovat valmiita sen omaksumaan. "Puhdaslihaa" on eri yhteyksissä kutsuttu in vitro -lihaksi, keinolihaksi, laboratoriolihaksi ja solulihaksi. Shapiron mukaan jokaiseen näistä liittyy kuitenkin ongelmia. Kuluttajat eivät esimerkiksi niitä ymmärrä tai ne aiheuttavat tunteen "luonnottomasta" tuotteesta. Shapiron lanseeraamalla termillä puhdasliha on tarkoitus viestittää, että tuotteessa ei ole antibiootti- tai ulostejäämiä.

Kirjassa Shapiro käy varsin yksityiskohtaisesti läpi, kuinka puhdaslihan kehitys on edennyt 1800-luvun lopulta ajatustasolta nykypäivään, jolloin tuotetta on jo maistettu televisiokameroiden edessä. Itselleni uutta tietoa oli, ettei ajatusta olisikaan ensimmäisenä esittänyt Winston Churchill, josta myöhemmin tuli Iso-Britannian pääministeri, esseessään "Fifty Years Hence" 1931, vaan ranskalainen kemian professori Pierre-Eugene-Marcellin Berthelot jo vuonna 1894. Berthelot oli jo tuolloin arvioinut, että ihmiset eivät enää vuonna 2000 söisi kuolleiden eläinten lihaa vaan sen laboratoriossa tuotettua vastinetta. Erityisen pitkästi kirjassa käydään läpi hollantilaisen professorin Mark Postin siirtymistä lääketieteen puolelta tutkijaksi, joka lopulta tuotti ensimmäisen syötävän laboratoriossa kasvatetun puhdaslihapihvin.

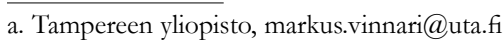


Kirjan jälkimmäinen osa keskittyy siihen, kuinka nykytilasta päästään eteenpäin. Yhtenä ehdotuksena kirjassa esitetään, että kuluttajat pitäisi ensin tutustuttaa solutuotannon mahdollisuuksiin tuomalla markkinoille nahkatuotteita, jotka on kasvatettu soluista laboratoriossa. Perusteluina tälle on, että nämä tuotteet olisi helpompi saada läpi viranomaiskäsittelystä, niiden tuottaminen olisi yksinkertaisempaa ja kuluttajien olisi niihin mutkattomampaa tutustua kuin suun kautta nautittaviin tuotteisiin.

Toisessa osassa käsitellään myös, kuinka eri yritykset kohdistavat resursseja niin naudanlihan kuin esimerkiksi broilerinkin korvaamiseen kuluttajien ruokapöydissä. Myös eri maitotuotteiden, kananmunien ja esimerkiksi gelatiinin korvaamiseen keskittyvistä yrityksistä kirja tarjoaa esimerkkejä. Kirja antaa kattavan kuvan siitä, miksi eri toimijat ovat mukana kehittelemässä ratkaisuja eri kestävyyden näkökulmista ruokakysymykseen: osaa ajaa huoli ilmastonmuutoksesta ja toisille taas eläinoikeuskysymykset ovat etusijalla. Ratkaisuja haetaan myös hyvin erilaisilla menetelmillä. Osa yrityksistä keskittyy hakemaan ratkaisuja soluviljelmistä ja osa taas pyrkii tuottamaan lihaa korvaavia tuotteita yhdistelemällä erilaisia ominaisuuksia eri kasviperäisistä raaka-aineista.

Kirja antaa valaisevan kuvan siitä, kuinka muutaman toimijan usko asiaansa on mahdollistanut heidän yrityksiensä perustamisen. Lisäksi kirja antaa mielenkiintoisen ikkunan nykyiseen startupfirmojen täyttämään yritysmaailmaan, jossa päätöksiä hyvinkin suurista summista tehdään varsin nopeasti erilaisten lyhyiden myyntipuheiden perusteella.

Kirjassa on muutamia avauksia, jotka olisivat mielestäni ansainneet osakseen enemmän pohdintaa. Edistetäänkö esimerkiksi näiden uusien tuotteiden kehitystä parhaiten panostamalla yrityksissä vai yliopistoissa tapahtuvaan tuotekehitykseen? Yritysmaailma toki tarjoaa nopeamman väylän varsinaisiin tuotteisiin, mutta akateeminen tutkimus mahdollistaisi tuotetun tiedon leviämisen laajempaan käyttöön. Vastaus saattaa löytyä jostakin näiden kahden ääripään välimaastosta. Lisäksi valitettavan monet yritysesimerkit ovat peräisin Yhdysvalloista ja kehitysaskeleet, joita muualla maailmassa on otettu, eivät mielestäni saa ansaitsemaansa huomiota.

Kirja tarjoaa kuitenkin hyvän katsauksen puhdaslihan ja muiden eläinperäisten tuotteiden korvaajien kehityksestä kiinnostuneille lukijoille. Kannattaa kuitenkin huomioida tekstin olevan suunnattu suurelle (yhdysvaltalaiselle) yleisölle eli se on lukukokemuksena varsin kevyt. Osalle väitteitä ei juurikaan esitetä perusteluja ja yhteiskunnallinen muutosprosessi nähdään varsin teknologiauskoisten lasien lävitse. Kirja ei myöskään sisällä varsinaista lähdeluetteloa, vaan tutkimuksiin viitataan tekstin sisällä, mikä tietysti hankaloittaa niiden etsimistä tarkempaa tutustumista varten. Ei voi kuitenkaan kiistää, etteikö kirjan suosio osaltaan puoltaisi sitä, että se kannattaa ainakin jokaisen ruokatutkijan lukea läpi. Mielenkiintoista on nähdä, kuinka suuri vaikutus näillä tuotteilla tulee lopulta olemaan tulevaisuuden ruokapöydissä. Pieni insinööri sisälläni uskoo, että varsin huomattava. vaikutus näillä tuotteilla tulee lopulta olemaan tulevaisuuden ruokapöydissä. Pieni insinööri sisälläni uskoo, että varsin huomattava.

\title{
Annika Lonkila ${ }^{a}$
}

\section{Tieteellisiå taruja elåimistå}

\author{
Vinciane Despret: \\ What would animals say if we asked them the rights questions? Vinciane Despret, \\ University of Minnesota Press 2016.
}

Belgialainen tieteenfilosofi Vinciane Despret tarttuu valtaviin, tieteen ja ihmisyyden perusteita ravisteleviin kysymyksiin: mitä luulemme tietävämme eläimistä ja mitä todella voimme tietää niistä. Millaisia kysymyksiä esitämme eläimille, ja miten löytämämme vastaukset vaikuttavat

a. Itä-Suomen yliopisto, annika.lonkila@uef.fi 